\title{
Ecological Aspects and Conservation of Wild Grapevine Populations in the S.W. of the Iberian Peninsula
}

\author{
M.A. López, R. Ocete and A. Gallardo \\ Laboratorio de Zoología Aplicada \\ (Sección de Sanidad de la Vid) \\ Facultad de Biología \\ University of Sevilla \\ Avda. Reina Mercedes, 6 \\ 41012- Sevilla \\ Spain \\ M. Cantos and A. Troncoso \\ IRNAS (CSIC) \\ Avda. Reina Mercedes $\mathrm{n}^{\circ} 10$ \\ P.O.Box 1052, 41080. Sevilla \\ Spain \\ I. Gómez \\ Departamento de Cristalografía \\ Mineralogía y Química Agrícola \\ Facultad de Química, University of Sevilla \\ C/ Profesor García González, s/n. 41071-Sevilla \\ Spain
}

Keywords: ecology, in vitro propagation, sanitary state, Vitis vinifera sylvestris

\begin{abstract}
Populations of wild grapevine, Vitis vinifera L. subsp. sylvestris (Gmelin) Hegi, were discovered in S.W. of the Iberian Peninsula over the last years. Location, ecological aspects, sanitary characteristics, including the ELISA test to detect specific virus attack, are described. In vitro propagation and conservation are also considered. The paper also contains a global description of female and male individuals. This material could be used to start breeding programs of cultivated varieties and also to restore riverbank forests, which constitute one of the worst preserved ecosystems in the area.
\end{abstract}

\section{INTRODUCTION}

The European wild grapevine, Vitis vinifera L. subsp. sylvestris (Gmelin) Hegi, is cited as an autochthonous and dioecious relative of cultivated vines (Heywood \& Zohary, 1995). The constant anthropic destruction of wild vines, consequence of forest exploitations, public works and cultivation, was made clear by Issler (1938). So, some incipient measures of protection were carried out in Germany (Kleeberger, 1940), after the massive destruction of vines situated in the riverbanks of the Rhin during the canalization process.

The paper published by Arnold et al. (1998) revealed the worrying state of the wild grapevine in alluvial and colluvial forests of European Countries. In the case of Spain, the big population described by Clemente y Rubio (1807) near the mouth of the Guadalquivir river (Pinar de la Algaida, Andalucía), which is the first scientific reference of wild grapevines in Spain, is today reduced to only 4 individuals.

Our observations during the last 10 years indicate that Spanish and Portuguese populations are constantly dwindling due to the shortage of a legislation intended for their specific conservation due to the idleness of the central and regional administrations.

Viticulture has a social and economic importance within agricultural production of Portugal and Spain, where it is necessary to carry out future breeding programs of varieties to be used in Integrated Production. On the other hand, wild grapevines must be also used in the restoration of alluvial and colluvial forests, which are ecosystems on the downgrade. According to both aims, our team is carrying out a new carthographycal survey in the S.W. of the Iberian Peninsula, namely in Ossa-Morena mountain range (Portugal-Spain), in territories belonging to the provinces of Córdoba, Sevilla and Huelva, in Andalucía and Extremadura, and to the Portuguese region of Alentejo, along $300 \mathrm{~km}$. 
After the description of the grapevine populations in their habitats, a good propagation method for their better conservation, starting with a few plant material that could give quickly a high number of plants, is necessary. According to the results obtained with cultivated grapevine plant species (Brendel, 1986; Troncoso et al., 1988; Gray and Benton, 1991; Sarmiento et al. 1992; Cantos et al., 1993; Wetzstein and Myers, 1994; Meyerson et al., 1995), the in vitro culture could be the appropriate method to reach that goal. In consequence, work tries to set up an in vitro method for the propagation of wild grapevine plant.

\section{MATERIAL AND METHODS}

The study of the cited mountain range was carried out between 1990 and 2001. Between May and June (flowering time), the sex of the vines was checked in order to demonstrate they were dioecious and so belonging to subsp. sylvestris and not escaped from cultivated vineyards.

In reference to the habitats where wild vines are growing, their main botanical supporters were identified and samples of soils from each location were analysed according to the protocol of the official method published by MAPA in 1982. Profiles were classified following the FAO-ISRIC-ISSS (1998) criteria.

With the aim to detect infestations and infections affecting vines, roots were uncovered to a maximum depth of $50 \mathrm{~cm}$ and examined for the presence of phylloxera, fungi and nematodes. In the aerial part of each plant, the first $2 \mathrm{~m}$ of the stem and 50 leaves, chosen at random, from 10 shoots were observed. Elisa test to determinate the presence of Grapevine fanleaf virus (GFLV) was made from 3 leaves of each plant, according to the procedure of Gugerli et al., (1984).

Cuttings from the different wild grapevine plants of the considered area were taken. From these cuttings, uninodal explants, $1 \mathrm{~cm}$ length were prepared. The explants were disinfected by the following steps: a) washing with water and a detergent and gently rinsing with distilled water; b) immersion in $70 \%$ ethanol for $45 \mathrm{~s}$; c) immersion in $45 \%$ sodium hypoclorite (3.5\% active chlorine) after addition of some drops of Tween-20 (20 min at $30^{\circ} \mathrm{C}$ with stirring); d) gently rinsing with distilled, sterilised water.

After disinfection, the explants were placed individually in sterile test tubes $(25 \times 150 \mathrm{~mm})$ with $8 \mathrm{ml}$ of "VID" medium (Troncoso et al., 1990) with 6\% agar. Each tube was covered with a plastic cap, sealed with parafilm and placed in a growth chamber at $23 \pm 2^{\circ} \mathrm{C}, 30 \mu \mathrm{mol} . \mathrm{m}^{-2} \mathrm{~s}^{-1}$ of light intensity and $16 \mathrm{~h}$ photoperiod.

After 50 and 60 days of in vitro culture, the parameters indicated in the Tables 2 and 3 respectively, were measured.

For the transplanting and hardening of the in vitro plants to outdoor conditions, the method indicated by Cantos et al. (1993) was followed.

\section{RESULTS AND DISCUSSION}

Coordinates of sites found from Cordoba province to Alentejo and the main botanical supporters of the grapevines are included in the next list. Córdoba: 30SUH8412, 30SUH8512, 30SUH8612, 30SUH8613, 30SUH8712, 30SUH8713, 30SUH8719, 30SUH8819, 30SUH8820, 30SUH8821，30SUH6416，30SUH6516，30SUH6615, 30SUH5601, 30SUH5400, 30SUH5401, Sevilla: 30STG4277, 30STG4378, 30STG4478, 30STG4578, 29SQB4772, 29SQB4773, 29SQB4973, Huelva: 29SQB1795, 29SQB1994, 29SQC0000, 29SPC9709, 29SPC8819, 29SPC8223, 29SPC8818, 29SPC6305; Badajoz: 29SQC0634, 29SQC0733, 29SQC0734, 29SQC0426, 29SQC0526, 30SPC9234, 30SPC 923530SPC9239, 30SPC9240, 30SPC9135, 30SPC9136, 30SPC9236, 30SPC9237, 30SPC9638, 30SPC9639 O Alentejo29SPC7822, 29SPC7823, 29SPC7923, 29SPC4121,29SPC45, 29SNC8466. The main supporters are Alnus glutinosa Gaertner, Crataegus monogyna Jacq., Ficus carica L., Fraxinus angustifolia Valh, Nerium oleander Vahl., Olea europea L., Pistacia lentiscus L., Populus nigra L., Populus alba L., Quercus rotundifolia L., Quercus rotundifolia L., Retama sphaerocarpa (L.) Boiss., Rubus ulmifolius Schott, Salix alba L. and Securinega tintorea (L.). 
A global description of these wines is shown in Ocete et al., 1999.

Range of the results of physic-chemical analysis of soils are shown in Table 1.

These results indicate that soils where the wild grapevine populations are growing present a bare development and all the profiles are very similar and were classified as Eutric Fluvisols.

No symptoms caused by injurious species were found on roots.

On the aerial part, the main infestation were caused on leaves by the erineum strain of Colomerus vitis (Pagenstecher) (Acari, Eriophyidae). Tetranychus urticae Koch (Acari, Tetranychidae) is sometimes present in the sunny side of the riverbank forests, specially in the case of the Sevilla province, where the leafhopper Jacobiasca lybica (Bergenin \& Zanon) (Homoptera, Cicadellidae) also causes some damages.

Symptoms caused by the powdery mildew, Uncinula necator (Schw.) Burr. are often observed on leaves, during spring and summer times, and on clusters and sarments. Also, some leaves with oil spots caused by the downy mildew, Plasmopara viticola (Berk. \& Curt.) Berk. \& de Toni, are registered in almost all the populations.

On the other hand, no symptoms of GFLV, which constitutes the main viral infection in all over the vineyards around Ossa-Morena mountain range, were found on shoots in the field. Also, all the Elisa tests were negative for this virus.

The list of pests and diseases affecting wild grapevines is very similar in the different European populations (Ocete et al., 1995; Ocete et al., 2000). Levels of infestation and infection are quite different, inside the same site, from one plant to other. It is, together with their morphologic differences, a demonstration of their high genetic diversity, which constitutes the key to avoid the genetic erosion and to start pest and disease resistance breeding programs and to restore the riverbanks forests.

Since no significant differences existed in the in vitro_behaviour of the explants from the different wild grapevine plants, the results were considered as an average of all plants and group of experiments.

The in vitro response of the explants obtained directly from the field cuttings (first in vitro culture) is indicated in Table 2. After 15 days of in vitro culture, $70 \%$ of the explants showed stem and leaf formation with good growth, and the 54\% of them had rooted, with an average of 3 roots per plant. This meant a very high in vitro precocity of the wild plant material, higher than the cultivated one, that normally needs at least 30 days of culture to reach similar level of development (Lakso et al., 1986; Villegas et al., 1992; Cantos et al., 1993; Gribaudo et al., 1995). After 40 days of in vitro culture, $90 \%$ of the explants had formed stem ( $8 \mathrm{~cm}$ length), buds and leaves (10 nodes) and roots (4 per plant as average). The remaining $10 \%$ of explants were contaminated. After 50 days, the above results did not change meaning that only 40 days of culture was necessary to get the maximum of in vitro plant development. These results allow to define a very high in vitro potential multiplication factor of 8 that is very interesting for the in vitro propagation of the wild grapevine. The results also confirm the good behaviour of the wild grapevine plant material, even better than that of the cultured grapevines in the same medium and conditions (Cantos et al., 1998; Troncoso et al., 1999).

The results of the second group of experiments, explants from in vitro plants of the first culture (Table 3 ) were quite similar to the above ones, and consequently confirmed the very good propagation capability of the wild grapevine plant material. In this case, after only 30 days a very high percentage of new plants was reached and after 60 days, $100 \%$ of the explants had formed plants. In these experiments there were no contaminated explants due to the fact that the original plant material came from in vitro culture.

It is interesting to emphasize that the aerial part (stem, leaves and buds) and radicular system of the wild grapevine explants, developed contemporarily in the same culture medium, giving new plants in only one in vitro culture. Although with a lower level of plant obtaining, Troncoso et al. (1999), reached similar results using the same medium, with some grapevine rootstocks. But in general, for in vitro grapevine plant material propagation, two culture treatments (multiplication and rooting) are necessary (Bass et al., 1988; Blazina et al., 1992). Thus the possibility of obtaining complete plants 
with only one in vitro culture was interesting, because it saves time and money in the propagation process.

Following the indicated method for plant transplanting and hardening to outside conditions, over $90 \%$ of surviving plant was reached.

From the results of these experiments, a good, quick and economical method, for the in vitro propagation of wild grapevine plants was set up. This will be of interest to help to the conservation of this threatened or endangered species.

\section{Literature Cited}

Arnold, C., Gillet, F. and Gobat, M. 1998. Situation de la vigne sauvage Vitis vinifera ssp. silvestris en Europe. Vitis, 37 4, 159-170.

Bass, P., Clog, E. and Walter, B. 1988. Improvements in apex culture in vitis species. Acta Hort 227, 485-488.

Blazina, I, and Ravnikar. 1992. Regeneration and micropropagation of the grapevine (Vitis Vinífera L. "Zelen") from shoot tip meristems. Acta Hort 300, 123-126.

Brendel, G. 1986 The in vitro culture of grapevine for rapid propagation within breeding programs. Wein-Wissen-Schaft. 41, 264-270.

Cantos M., Liñan J. Pérez-Camacho F.and Troncoso A. 1993. Obtención de plantas selectas de vid, variedad Zalema, libres de la virosis entrenudo corto. Actas de Horticultura Vol.II, 705-709.

Cantos, M., Esenarro, G., Liñán, J. and Troncoso, A. 1998. Efecto del ACR y otros reguladores sobre el desarrollo in vitro de plantas de vid de la variedad Zalema. XX Jornadas de Viticultura y Enología Tierra de Barros. Almendralejo. 157-163.

Clemente Rubio, S.R. 1807. Ensayo sobre las variedades de vid que vegetan en Andalucía. Imp. Villalpando. Madrid.

FAO-ISRIC-ISSS. 1998. World Reference Base for Soil Resources.Roma.

Gray, D.J. and Benton, C.M. 1991. Micropropagation and plant establishment of muscadine grape. Proc-Annu-Meet-Fla-State-Hortic-Soc. [S.1.] : The Society. June. v. 103, 300-302.

Gribaudo, I., Morte, A. and Schubert, A. 1995. Use of gentian violet to differentiate in vitro and ex vitro-formed roots during acclimatization of grapevine. Plant-cell,-tissue-organcult. v. 41 (2), 187-188.

Gugerli, P., Brugger, J. and Bovey, R. 1984. L'enroulement de la vigne mise en évidence de particules virales et développment d'une méthode inmunoenzimatique pour le diagnostic rapide. Revue suisse Vitic. Arboric. Hort, 16 (5), 229-304.

Heywood, V. and Zohary, D. 1995. A Catalogue of the Wild Relatives of Cultivates Plants Native to Europe. Flora Mediterranea, 5, 375-415.

Issler, E. 1938 La vigne sauvage des fôrets de la vallée rhénane est elle en voie de disparition?. Bull. Assoc. Philomat. Alsace Lorraine, 8 (5), 413-416.

Kleeberger, K. 1940. Die Wildrebe im Stadtpark unter Naturschutz.Heimatblätter für Ludwigshafen am Rhein und Umgebung, 29 (14), 1-4.

Lakso, A.N., Reisch, J., Mortensen, J.and Roberts, M.H. 1986. Carbon dioxide enrichment for stimulation of growth of in vitro-propagated grapevines after transfer from culture. J. Amer. Soc.Hort. Sci. 111 (4), 634-638.

M.A.P.A. 1982. Métodos oficiales de análisis de suelos. Ministerio de Agricultura, Pesca y Alimentación. Madrid.

Meyerson, M.E., Benton, C.M. and Gray, D.J. 1995. A comparison of shoot micropropagation among bunch and muscadine grape species and cultivars. Proc-annumeet-Fla-State-Hort-Soc. [S.1.]: The Society, June. v. 107, 311-312.

Ocete, R, López, M.A., Pérez, M.A., del Tío, R. and Lara, M. 1999. Las poblaciones españolas de vid silvestre: Características de un recurso fitogenético a conservar.Monografías INIA: Agrícola 3: 1-52. Madrid.

Ocete, R., Del Tío, R. and Lara, M. 1995. Les parasites des populations de la vigne sylvestre, Vitis vinifera silvestris (Gmelin) Hegi, des Pyrénées Atlantiques (France). Vitis, 34 (3), 191-192.

Ocete, R., López, M.A., Pérez, M.A., Arnold, C. and Ferragut, F. 2000. Prospección de los 
artrópodos fitófagos, auxiliares y enfermedades en poblaciones europeas de vid silvestre, Vitis vinifera L. subesp. sylvestris (Gmelin) Hegi. Bol. San. Veg. Plagas, 26, 171-184.

Sarmiento, R., Villegas, A., Mazuelos, C., García, J.L. and Troncoso, A. 1992. Influence of the nitrogen source and concentration on $\mathrm{N}$ fractions and free amino acid levels of grapevine explants. Plant and Soil 144, 255-258.

Troncoso, A., Villegas, A. and Cantos, M. 1990. Growth and mineral composition of grapevine rootstock cultured in vitro with different levels of ammonium nitrate. Plant Nutrition, Physiology and Applications. Kluwer Academic Publishers. Holanda. pp 581584.

Troncoso, A., Cantos, M., Liñán, J., Prieto, J. and Sarmiento, R. 1988. The use of "in vitro" culture and tubular container system to propagate selected grapevine plants for sherry wine production. Acta Hort., 227, 358-362.

Troncoso, A., Matte, C., Cantos, M. and Lavee, S. 1999. Evaluation of salt tolerance in vitro-grown grapevine rootstock varieties. Vitis 38 (2), 55-60.

Villegas, A., Mazuelos, C., Cantos, M. and, Troncoso, A. 1992. Influencia del N sobre el desarrollo in vitro del portainjerto de vid 161-49. Suelo y Planta, 2, 529-539.

Wetzstein, H.Y. and, Myers, S.C. 1994. Vegetative and yield component characteristics of micropropagated muscadine grape (Vitis rotundifolia Michx.). J-hortic-sci. Ashford: Headley Brothers Ltd. July. v. 69 (4), 747-753.

\section{$\underline{\text { Tables }}$}

Table 1. Main physical and chemical data of soils.

Mechanical Analysis and $\mathrm{pH}$

\begin{tabular}{ccccc}
\hline \multicolumn{2}{c}{ MECHANICAL ANALYSIS (\%) } & \multicolumn{2}{c}{$\mathrm{PH}$} \\
\hline Sand & Silt & Clay & $\mathrm{H}_{2} \mathrm{O}$ & $\mathrm{KCl}$ \\
$58,81-83.33$ & $10,96-30,02$ & $5,71-11,46$ & $5,73-7,29$ & $5,53-6,89$ \\
\hline
\end{tabular}

Cation Exchange Capacity and Base Saturation percentage

\begin{tabular}{ccccccc}
\hline \multicolumn{7}{c}{ CATION EXCHANGE CAPACITY (meq/Kg) } \\
\hline $\mathrm{Ca}$ & $\mathrm{Mg}$ & $\mathrm{Na}$ & $\mathrm{K}$ & $\mathrm{T}$ & $\mathrm{S}$ & $\mathrm{V}$ \\
$29,00-$ & $4,00-33,33$ & $3,03-4,63$ & $1,67-3,20$ & $15,07-$ & $38,12-$ & $\mathrm{SAT}$ \\
118,50 & $4,02,83$ & 155,25 & $\mathrm{~S}$ \\
\hline
\end{tabular}

Organic Matter, Nitrogen and Micronutrients

\begin{tabular}{lccccc}
\hline & & & MICRO & \multicolumn{2}{c}{ NUTRIENTS $(\mathrm{g} / \mathrm{Kg})$} \\
\hline O.M. & $\mathbf{N}$ & $\mathrm{Fe}$ & $\mathrm{Cu}$ & $\mathrm{Mn}$ & $\mathrm{Zn}$ \\
$0,00-1,56$ & $0,54-1,38$ & $0,0004-$ & $0,0004-$ & $0,0002-$ & $0,0002-$ \\
& & 0,0011 & 0,0005 & 0,0005 & 0,0007 \\
\hline
\end{tabular}

Macronutrients, Phosphorus and Calcium Carbonate

\begin{tabular}{lccccc}
\hline \multicolumn{5}{c}{ MACROELEMENTS $(\mathrm{g} / \mathrm{Kg})$} \\
\hline $\mathrm{P}$ & $\mathrm{Ca}$ & $\mathrm{Mg}$ & $\mathrm{Na}$ & $\mathrm{K}$ & $\mathrm{CaCO}_{3}$ \\
$0,026-0,102$ & $1,00-2,54$ & $0,08-0,50$ & $0,13-0,18$ & $0,08-0,14$ & 0,00 \\
\hline
\end{tabular}


Table 2. In vitro behaviour of wild grapevines explants; average characteristics of the obtained plant (first culture)

\begin{tabular}{lccc}
\hline & \multicolumn{2}{c}{ Days of Culture } & 50 \\
Controls & 15 & 40 & 90 \\
\% of formed stem & 70 & 90 & 8 \\
Stem length (cm) & 2.5 & 8 & 10 \\
Number of buds (nodes) & 2 & 10 & 2 \\
Number of lateral shoots & 0 & 2 & 90 \\
$\%$ of rooting & 54 & 90 & 4 \\
Number of roots & 3 & 4 & 8 \\
Potential factor of in vitro & - & 8 & \\
multiplication & & & \\
\hline
\end{tabular}

Table 3. In vitro behaviour of wild grapevines explants; average characteristics of the obtained plant (second culture)

\begin{tabular}{lcc}
\hline & & Days of culture \\
\hline Controls & 30 & 60 \\
\hline$\%$ of formed stem & 83 & 100 \\
Stem length (cm) & 3.5 & 7.5 \\
Number of buds (nodes) & 3 & 10 \\
Number of lateral shoots & 0 & 2 \\
$\%$ of rooting & 75 & 100 \\
Number of roots & 4 & 5 \\
Potential factor of in vitro & - & 8 \\
multiplication & & \\
\hline
\end{tabular}

